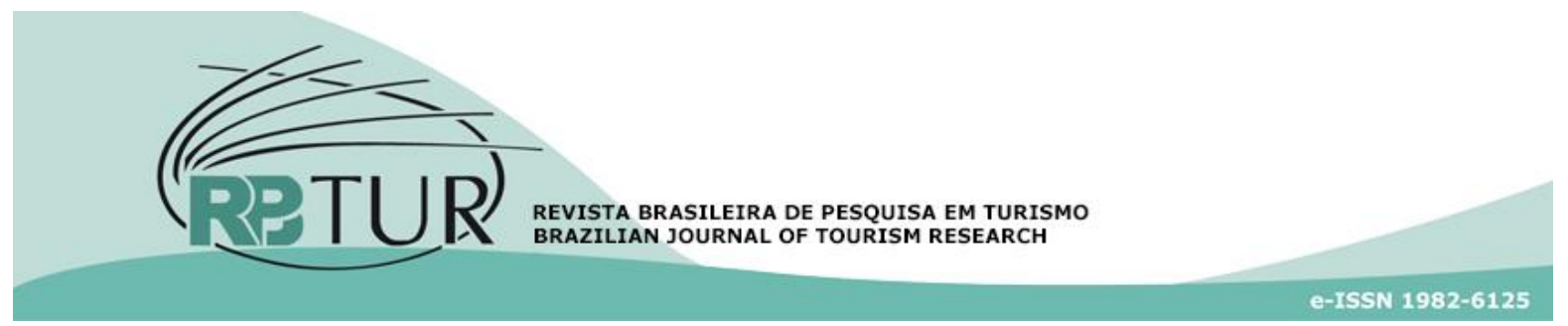

\title{
Papers
}

\section{Mexico and Uruguay inbound tourism demand}

\section{A demanda turística de México e Uruguai}

\section{La demanda turística de México y Uruguay}

\author{
Gabriela Mordecki ${ }^{1}$, Ana Leiva², Nathalie Desplas ${ }^{3}$ \\ 1 University of the Republic (UdelaR), Montevideo, Uruguay \\ 2 University of Oslo, Finland \\ ${ }^{3}$ Monterrey Technological Institute (TM), Chihuaua, Mexico
}

Keywords:

Tourism demand;

Cointegration;

Real exchange rate;

Mexico;

Uruguay.

JEL: C32, F14, F41

Palavras-chave:

Demanda turística

Cointegração;

Taxa de câmbio real;

México;

Uruguai.

JEL: C32, F14, F41.

\section{Abstract}

The main objective of this paper is to estimate the tourism demand for Mexico and Uruguay, two very different countries, but for both of which tourism is an important activity, and mainly originating from a large neighbor. We try to analyze whether the determinants of tourism demand differ depending on the size of the country, or if being a neighboring country is the main determinant. So, we analyze the relationship between the number of American tourists visiting Mexico and Argentinian tourists visiting Uruguay, and the inbound tourists' income and the bilateral real exchange rate (RER) between the visiting country and the hosting country, following the Johansen's methodology. We found one cointegration relationship for each country, where the income-elasticity was greater than 2 for American tourists visiting Mexico, and nearly 3 for Argentinian tourists visiting Uruguay. Bilateral RERs were also significant in both models. Moreover, forecasts show the impacts of institutional changes on the tourism sector. The impact of arrival of President Macri to power was positive for Argentinian tourists visiting Uruguay, but President Trump's arrival in the US was negative for American tourists visiting Mexico.

Resumo

O principal objetivo deste documento é estimar a demanda do México e do Uruguai, dois países muito diferentes, mas o turismo para ambos é uma atividade relevante, e também os turistas vêm principalmente de um grande vizinho. Procuramos analisar se os determinantes da demanda turística diferem em função do tamanho do país, ou se ser um país vizinho é o principal determinante. Portanto, analisamos a relação entre o número de turistas norte-americanos que visitam o México e turistas argentinos que visitam o Uruguai, considerando o nível de renda dos turistas e a taxa de câmbio real bilateral (TCR) entre o país visitante e o anfitrião, seguindo a metodologia de Johansen. A partir daí, encontramos uma relação de cointegração para cada país, onde a elasticidade-renda resultou maior que 2 para turistas americanos no México e quase 3 para turistas argentinos no Uruguai. As TCRs bilaterais também foram significativas em ambos os modelos. Além disso, as projeções estimadas mostram as consequências das mudanças institucionais no setor de turismo. A chegada do presidente Macri ao poder foi positiva para os turistas argentinos que visitaram o Uruguai, mas a chegada do presidente Trump aos Estados Unidos foi negativa para os turistas americanos que visitaram o México. 
Palavras clave:

Demanda turística;

Cointegración

Tipo de cambio real;

México;

Uruguay.

JEL: C32, F14, F41

Peer reviewed

Received in: 05/12/2018.

Accepted in: 23/03/2019.

\begin{abstract}
Resumen
El objetivo principal de este documento es estimar la demanda turística de México y Uruguay, dos países muy diferentes, pero el turismo para ambos resulta una actividad relevante, y además los turistas provienen principalmente de un gran vecino. Intentamos analizar si los determinantes de la demanda turística difieren según el tamaño del país, o si ser un país vecino es el principal determinante. Por lo tanto, analizamos la relación entre el número de turistas estadounidenses que visitan México y de los turistas argentinos que visitan Uruguay, considerando el nivel de ingreso de los turistas y el tipo de cambio real (TCR) bilateral entre el país visitante y el anfitrión, siguiendo la metodología de Johansen. A partir de ahí, encontramos una relación de cointegración para cada país, donde la elasticidad ingreso resultó mayor que 2 para los turistas estadounidenses en México, y cerca de 3 para los turistas argentinos en Uruguay. Los TCR bilaterales también resultaron significativos en ambos modelos. Además, las proyecciones estimadas muestran las consecuencias de los cambios institucionales sobre el sector turístico. La llegada del presidente Macri al poder fue positiva para los turistas argentinos que visitaron Uruguay, pero la llegada del presidente Trump a los Estados Unidos fue negativa para los turistas estadounidenses que visitaron México.
\end{abstract}

How to cite: Mordecki, G; Leiva, A.; Desplas, N. (2019). Mexico and Uruguay inbound tourism demand. Revista Brasileira de Pesquisa em Turismo, São Paulo, 13 (3), p. 161-182, sep./dec. http://dx.doi.org/10.7784/rbtur.v13i3.1582

\section{INTRODUCTION}

Tourism is an important engine of the economic growth and development of countries (Brida Lanzilotta \& Risso, 2010; Tang \& Tan, 2013; Schubert, Pablo-Romero \& Molina, 2013; Schubert, Brida \& Risso, 2011; WTTC, 2011; Desplas, 2010). Tourism mobility is increasing over time and space allowing growing destination country income, employment, foreign exchange earnings, and equilibrium in the balance of payments. Experts argue that the tourism industry continues to be one of the world's largest sectors with a decisive impact on the economic welfare of local populations, the entrepreneurship activity, the direct and indirect tourists' spending due to the multiplier effect. In addition, recently, the tourism-growth literature explains that tourism is perceived in many regions as a crucial source of income and economic resources for their own expansion and development. This is the case, for example, in developing countries (Ghimire, 2013), Malaysia (Tang \& Tan, 2013), Pakistan (Adnan \& Ali, 2013), and Cyprus, Latvia and Slovakia, (Chou, 2013); China (Chon, Pine, Lam \& Zhang, 2013). In other places like Singapore (Timothy, 2014), Hong Kong (HK Tourism Board, 2014) or Mediterranean countries (Tugcu, 2014), Latin-American countries (Peterson, Cadernas \& Harrill, 2014), Mexico (UNTWO, 2014), the USA (White House, 2014), and European Countries in general (Costa, Panyik \& Buhalis, 2014) among others. Tourism is even more critical in a resource-poor environment, such as in small island destinations like Aruba (Ridderstaat, Croes \& Nijkamp, 2014), or Cape Verde (Ribeiro, Oom do Valle \& Silva, 2013).

Following Dritsakis (2004), the existence of favorable climatic or natural conditions or rich cultural attractions evidence in a country does not automatically guarantee its choice as a popular tourist destination. Nevertheless, in this case these factors are secondary, and the proximity and the historical ties with the origin countries, are the most important factors determining tourism. Mexicans receive US citizen visitors and Uruguay has Argentinian tourists as the most important inbound tourists, in both countries representing nearly $60 \%$ of total visitors (Ministry of Tourism, Uruguay and Tourism Secretary, Mexico).

Over the last decades-despite economic, security or health crisis-tourism experienced continued growth, innovation, and diversification, becoming "one of the largest and fastest-growing economic sectors in the world, where annual arrivals have shown virtually uninterrupted growth from 25 million in 1950, to 278 million in 1980, 528 million in 1995, 1,035 million in 2012, and 1,087 million in 2013" (World Trade Organization [UNWTO], 2014). In 2016, international tourist arrivals increased to reach a new record of 1,235 million. Following this path, Sánchez, Pulido and Cárdenas (2013) assess that tourism is expected to generate, over a ten-year horizon, 11.3 \% of world GDP and $8.3 \%$ of employment. 
In the USA, many middle-class consumers traveled within the region (Ghimire, 2013), in particular to Mexico. With 120 million inhabitants, $12,000 \mathrm{~km}$ of coastline and a strong diversity of climates, Mexico was the 8th most visited country by tourists in 2016 (CNET, 2017). In 2016 tourism activity represented 8.7\% of Mexican GDP and $4.8 \%$ of total employment (Mexico, 2016).

Uruguay is located between two neighbors: Argentina and Brazil, and with a very peculiar geographic and political structure that was defined by its history and ensuing development. The country has 3.3 million inhabitants, with $700 \mathrm{~km}$ of coastline over the Rio de la Plata, and a temperate climate. Argentinian tourists have historically been its main visitors, particularly in the main Uruguayan tourist resort, Punta del Este, 360 $\mathrm{km}$ away from Buenos Aires. The relevant periods for Argentinian tourists to come to Uruguay are the summer and winter holidays, and long weekends. Additionally, many of them have secondary private houses in Uruguay with family relationships, and/or investments and commercial interests.

Moreover, total yearly tourists are equivalent to about $90 \%$ of Uruguayan population and Argentinian tourists are nearly $60 \%$ of this total; this market share has remained the same over time. According to the World Travel and Tourism Council, in 2017 the total contribution of tourism activity represented 10.4\% of Uruguayan GDP and $10 \%$ of total employment.

The purpose of the present paper is to estimate the long-run inbound demands for USA tourism in Mexico and Argentinian tourism in Uruguay. As mentioned before these two countries (México and Uruguay) have in common that inbound tourism comes principally from a big neighbor. Our purpose is to compare both demands studying similarities and differences between them. We try to analyze if the determinants of tourism demand differ depending on the size of the country, or if being a neighboring country is the main determinant.

The present paper is organized as follows. The second section intends to describe the importance of tourism in Mexico and in Uruguay; section three presents the background and analysis framework; in section four we describe data and methodology. In the fifth section, we expose the main results. Finally, the sixth section draws some conclusions and final remarks.

\section{TOURISM SECTOR IN MEXICO AND URUGUAY}

\subsection{Mexico}

Mexico is the poorest country in North America and its Human Development Index (HDI) situated Mexico in $77^{\text {th }}$ place of 188 countries. In 2016, tourism activity represented $8.7 \%$ of Mexican GDP and $4.8 \%$ of total direct employment (Mexico, 2016). In 2016, the direct and indirect effect of the Tourism sector on employment, including jobs indirectly supported by the industry was $16.8 \%$ of total employment. Tourism is also important, generating foreign exchange income for the country. In 2016, tourism sector represented $5.3 \%$ of total Mexican exports and 3.3\% of total investment.

In 2016, more than 35 million tourists visited Mexico (9\% increase), which represents a high growth driven by the US demand despite a "warning" advising US citizens to keep a low profile because of security concerns. Mexico's tourism industry boomed in 2015: of the total of international passengers arriving in the country, $57.3 \%$ were US citizens, confirming that its big neighbor remains its main tourist market. Furthermore, of the US tourists who traveled abroad, $18 \%$ made it to Mexico, a figure that shows a steady increase in market share to Mexico and a historical record in term of numbers. Mexico's Tourism Secretary plans to reach $20 \%$ in the next future. In 2015, were still the tourists that visited Mexico most for both recreational and business tourism. Almost 9 million entered the country by air in 2015, representing $17.8 \%$ of all US citizens traveling abroad by air (Mexico, 2016). According to Meré (2016), the Mexican airport that received the most Americans in 2015 was Cancun, followed by Mexico City. Finally, in terms of the high-end and luxury sector, Mexico ranks number one in the top 10 ranking, followed by Canada, Australia, New Zealand, United Kingdom, South Africa, and India, Chile, and China. This is especially accurate for the VIP tourists that appreciate the Mexican hospitality supply (Mexico, 2016). 


\subsection{Uruguay}

Uruguay is one of the smallest countries in South America. Situated between Brazil and Argentina, it has one of the lowest poverty levels and one of the highest life expectancies in Latin America, and its HDI places the country in 54th place out of 188 countries. According to the World Travel and Tourism Council, in 2017 the total contribution of tourism activity represented $10.4 \%$ of Uruguayan GDP and $10 \%$ of total employment. The Uruguayan Ministry of Tourism (Mintur) estimated the contribution of tourism to be about 7\% of GDP in 2011 (consider that the agricultural sector represented 9\% of GDP). Even more important is the contribution to the country's foreign exchange income, tourism being the main origin in 2016 at 2.1 billion dollars. It was also the most important product exported by Uruguay, whose growth depends on exports and in particular on tourism as analyzed in Brida et al. (2010). Tourism represented 14\% of total exports of goods and services in 2016, being very important for the external equilibrium of Uruguayan trade. As Brida et al. (2010) asserted, Uruguayan tourism has two main characteristics: a high dependence on Argentinian tourists and a strong seasonality. According to the Mintur statistics, in 2016, Argentinian spending represented $64.3 \%$ of total tourist expenditure.

In 2011, the World Tourism Organization (UNWTO), the UNWTO Themis Foundation and the IE Business School studied the Uruguayan case aiming to analyze "Uruguay Natural: The differentiation of an emerging tourism destination". This case study was to analyze the increase in expenditure per visitor, with growing tourism revenues in Uruguay during the last 10 years.

The Uruguayan government analyzed the potentialities of the tourism sector in 2009, (OPP, 2009) considering it as an engine of economic development in the future. They conclude that tourism could grow even more if the product is diversified and new alternatives are offered. Nowadays tourism is concentrated in the "sun and beach" product in summer seasons.

In order to increase private investment, the government developed an investment promotion system, but this has not been enough to overcome the geographic, seasonal and thematic concentration of tourism supply, basically due to the lack of an active approach to looking for new opportunities.

\section{BACKGROUND AND ANALYSIS FRAMEWORK}

Paraskevopolous (1977), Loeb (1982), Stronge and Redman (1982), Truett and Truett, (1987), Witt and Witt (1995), Mudambi and Baum (1997) and Song, Li, Witt and Fei (2010) present important research about the estimation of the determinants of tourism demand. Crouch (1995) find 80 empirical studies on the demand function for tourism while Song and Li's (2008) review published studies on modeling and predicting tourism demand since 2000. Most of these studies focused on income from outbound countries and the relative price of exported tourism services as the main determinants of tourism demand. Nurbaizura and Zainudin (2015) studied Malaysian tourism demand from several countries using a VEC Model and found a significant impact of the euro crisis. Cao, Li and Song (2017) study cross-country tourism in China, using a Global VAR, analyzing responses to shocks to the Chinese economy. Martins, Gan and Ferreira-Lopes (2017) consider three econometric models to determine the relationship between macroeconomic variables and tourism demand. They found that world GDP per capita is more important when explaining arrivals, but relative prices become more important when they use expenditures as the proxy for tourism demand.

Other researchers focused on Uruguayan tourism, studying the relevance of tourism activities on GDP growth (Brida et al., 2010) while Robano (2000), Altmark, Mordecki, Risso, and Santiñaque (2013) and Serviansky (2011) try to estimate the determinants of tourism demand. With different emphasis, those experts tried to find a relationship between real tourism spending and real income of foreign tourists.

Lim (1997) presents a review of more than 100 published studies of empirical models. Tourist arrivals/departures and expenditures/receipts have been the most frequently used dependent variables. The most popular explanatory variables used have been income, relative tourism prices, and transportation costs. Song and $\mathrm{Li}$ (2008) found that the methods used in analyzing and forecasting the demand for tourism have been more diverse than those identified by other review articles, and in addition to the most popular time-series and econometric models, several new techniques have emerged in the literature. 
Spain, a top 10 tourism country, appeared as the subject of diverse papers about demand determinants. Among them, demand is mainly studied with Vector Error Correction Models (VECM) trying to identify not only the characteristics of the economic agents that are demanding Spanish tourism but also competitors' influence on international demand. Through this approach, the authors try to identify Spain as a competing destination with countries of similar characteristics in the region.

Álvarez-Díaz, Otero-Giráldez and González-Gómez $(2012,2015)$ model Russian demand for Spanish destinations using cointegration and VEC models. The number of tourists is used as the dependent variable and the estimation of the income, price, and cross-price elasticities of the demand for Russian tourism in Spain is carried out, using Russian per capita income and Spanish and competitors' prices. The authors identify that those determinants are relevant to explain Russian demand. Previously, the same authors in a different paper studied tourism determinants by country, trying to explain them by income variations (using the Industrial Production Index, IPI) and prices (Consumer Price Index, CPI), once again using VEC models.

Including competitors' relative prices is not a new approach while studying Spanish tourism. González and Moral in their 1995 paper used this approach while analyzing international demand. In this case, internal as well as competitors' prices play a substantial role in determining international tourism demand.

Han, Durbarry and Sinclair (2006) describe international tourism from the USA to Europe with an "almost ideal demand system model". This model evidences the linkages between tourists' demand and relative prices, exchange rates and expenditure. The authors find that the different macro variables have different effects on the destinations. While US demand for France, Spain or Italy are highly influenced by prices, UK or Spain have a negative correlation with income.

Other particularities can be found when looking at the behavior of international tourism demand for Australian destinations. On the one hand, Lim and McAleer's (2001) paper models the quantity of tourists from Singapore using as explanatory variables income, relative prices with Australia and with competitors, as well as transportation costs. Similarly, to what has been used in the previous cases, the authors use a VEC model as well as a Johansen cointegration model and an Ordinary Least Squares (OLS) model.

Moreover, the same authors, in 2002, study the long-run relationship between Malaysian touristic demand and other macroeconomic variables such as income, relative exchange rate or price level, combined with transportation expenses using different models. Depending on the model chosen it is possible to identify effects from the different dimensions.

For the analysis of tourism demand to Mexico and Uruguay of the USA and Argentina we estimated two demand equations, considering income of the visitor's country and relative prices between guest and host countries, following the demand theory, where given the supply, the demand side depends on prices and income to determine the equilibrium point. In this case, as we have two countries, we must consider relative prices and exchange rates, so we use the bilateral real exchange rates of the USA and Mexico for one model, and Argentina and Uruguay for the other, with RER defined using Purchasing Power Parity (PPP) (Krugman \& Obstfeld, 2008):

$$
\mathrm{RER}_{\mathrm{ij}}=\frac{\mathrm{NER}_{\mathrm{i}} \times \mathrm{P}^{*}}{\mathrm{P}^{\mathrm{d}}}
$$

where RER $\mathrm{ij}_{\mathrm{j}}$ is the bilateral real exchange rate of country $i$ (Mexico or Uruguay) with the visitors' country $j$ (USA and Argentina), NER is the nominal exchange rate, $P^{*}$ are international prices and $P_{d}$ are domestic prices.

Karimi et al. (2015) estimated tourism demand for ASEAN countries through macroeconomic variables such as prices, exchange rate or investments, looking for cointegration between them. Pham et al. (2017) studied Chinese tourism demand in Australia using a dynamic time series estimator, and they found that income and price elasticities are quite high, for both the short- and long-run. Along the same line, Dritsakis (2004) estimated a cointegration vector for British and German tourists visiting Greece, including between other variables: prices, exchanges rates, and income. Also, for Greek tourism demand, Botzoris, Varagoulia, Profillidisa, Papadopoulosa \& Lathirasb (2014) used Johansen techniques to estimate short- and long-run cointegration equations of tourism demand. 
Following these authors, using the Johansen methodology, we will estimate inbound tourism demand for Mexico from the USA and for Uruguay from Argentina, obtaining price and income elasticities and short- and long-run equations to understand these demands, comparing the tourists' behavior, to give policymakers and private stakeholders important inputs to make decisions. The value added of this paper is the comparison of two apparently very different countries, Mexico and Uruguay, considering size, number of inhabitants and HDI index, but both with tourism as an important activity that contributes to GDP and employment. We use the same methodology and the same macroeconomic variables in the models, and we will compare the elasticities that emerge from the models.

\section{DATA AND METHODOLOGY}

In this study, we try to measure tourism demand comparing Mexico and Uruguay, two different countries, but strongly similar in terms of tourism industry relevance for growth, employment, and national income. Applying Johansen's $(1988,1992)$ methodology we will try to find a model for each country's tourism demand and then compare the results. As the variables' coefficients can be interpreted as elasticities, we will compare the results between countries, looking at similarities and differences between them.

\subsection{Data}

As we are estimating tourism demand functions for each country, we will have one variable representing the tourists' income and the other to represent relative prices between the visitor's and the country. To estimate the income of tourist source country, we have considered the IPI as a proxy, a commonly used variable, taking advantage of the monthly information provided. To estimate the relative prices between countries, we used the bilateral real exchange rate (RER) between countries. All the calculations of the RERs were made using the countries' administrative statistics. In all cases, the RERs have been calculated from the hosting country's point of view, so, as the index grows, it shows improved competitiveness of Uruguay or Mexico relative to Argentina or USA. Due to the availability of information, the period of study is from January 1998 to December 2015 , using monthly data and considering the log transformation of the series, to solve scale problems between the series.

Figure 1 shows the Uruguayan model series: Tour_Arg represents monthly Argentinian tourists' arrivals in Uruguay, IPI_Arg represents the Argentinian industrial production index used as a proxy for Argentinians income, and RER_Arg represents the bilateral real exchange rate between Argentina and Uruguay (it increases as Uruguayan competitiveness improves in relation to Argentina). There is a marked seasonality in the tourists and the IPI series. As far as Argentinian tourism is concerned, it is a consequence of the fact that the greatest tourist flow occurs during summer holidays, which correspond to the months of January and February each year. For both series, seasonality has been corrected for in the models, where the series were considered in logarithmic form, introducing seasonal dummy variables. This Figure highlights the 2001-2002 regional crisis, with the high devaluation in Argentina (December 2001) and in Uruguay (from August 2002) reflected in the bilateral RER path, and in the downward jump in the industrial production and in tourist arrivals. 
Figure 1 - Uruguayan Series

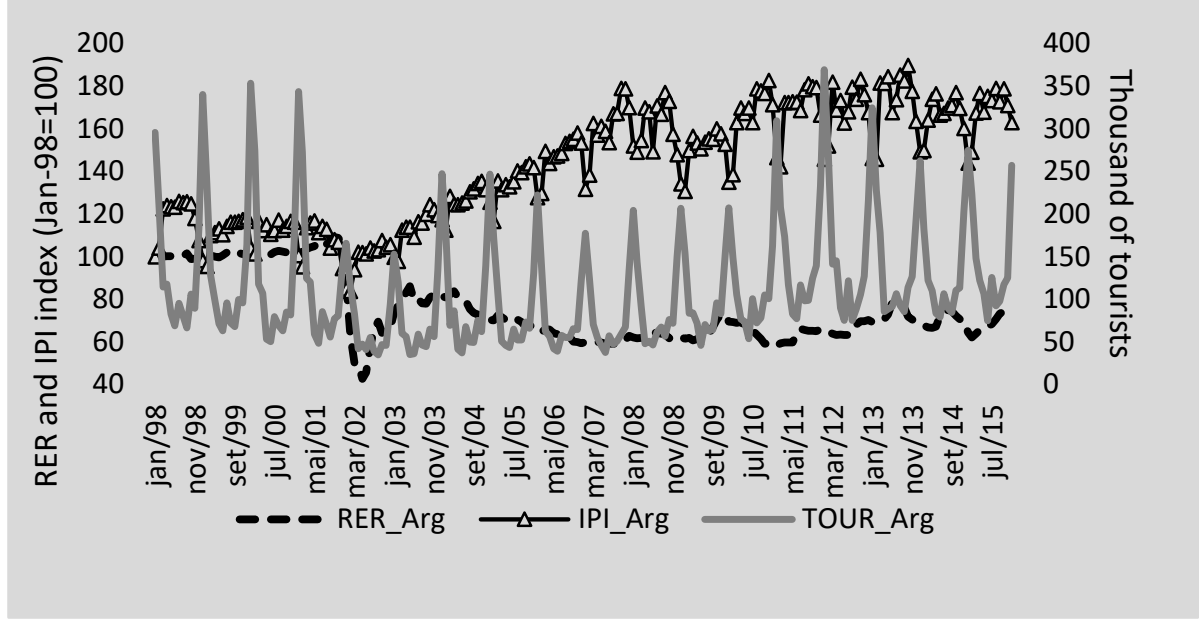

Source: Uruguay Ministry of Tourism, Argentina Ministry of Economics, our own RER calculations from Uruguay and Argentina Central Banks' information

In Figure 2, we show the time series of the Mexican model: the US monthly tourists arrivals in Mexico (TOUR_USA), the bilateral real exchange rate between Mexico and the USA (RER_USA: it increases as Mexican competitiveness improves in relation to the USA) and the US IPI (IPI_USA), as a proxy of Americans' income. For these series, only tourist arrivals show seasonality. The seasonality, in this case, originates from two periods in the year of high tourist influx from the USA to Mexico, one in July and August for summer holidays and another in December due to the Christmas and New Year holidays. So, seasonal dummy variables have been added in the models to correct seasonality in the tourist arrival series.

For both models, other dummy variables have been added to correct for outliers and other atypical values in the series.

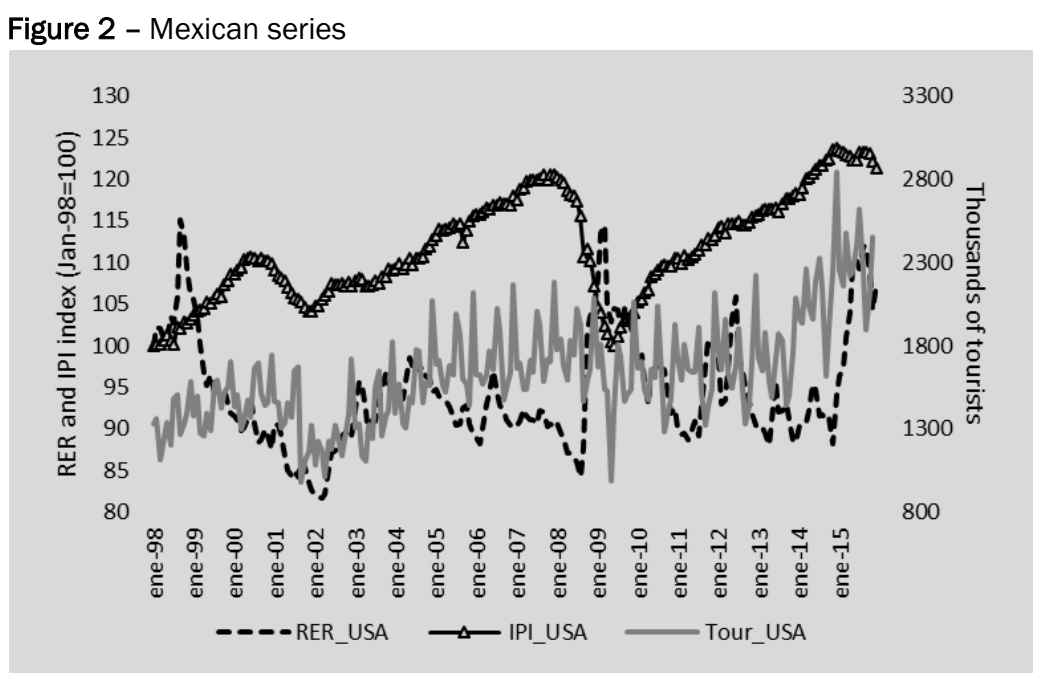

Source: INEGI (Mexico) BLS (USA), our own RER calculations from Mexico Central Bank and Federal Reserve information

\subsection{Methodology and Model}

In this work, through the Johansen $(1988,1992)$ methodology we try to find a long-run relationship representing tourism demand for both countries, the most important source of tourism for each being US tourists for Mexico and Argentinian tourists for Uruguay.

Following the literature, we define the tourism demand equation as: 


$$
\mathrm{x}_{\mathrm{m}, \mathrm{u}}=\alpha_{\mathrm{m}, \mathrm{u}} \mathrm{RER}_{\mathrm{m}, \mathrm{u}}+\beta_{\mathrm{m}, \mathrm{u}} \mathrm{IPI}_{\mathrm{m}, \mathrm{u}}+\gamma_{\mathrm{m}, \mathrm{u}}
$$

Where $x$ is the tourist demand, for country $\mathrm{m}=$ Mexico and $\mathrm{u}=$ Uruguay.

RER is the country's bilateral real exchange rate with the corresponding partner: Argentina for Uruguay and the USA for Mexico.

IPI is the Industrial Production Index used as a proxy for the origin country's income: Argentina for Uruguay and the USA for Mexico.

To analyze the series, first, we must study the stationarity performing unit root tests. In Table 1 we show the results of the augmented Dickey-Fuller (ADF) test. All the variables were considered as logs, so the variables names have an $L$ in front of their names.

As a result of the ADF test, all the variables resulted integrated of first order, I (1). Because of the non-linearity of the series, we decided to apply the Johansen $(1988,1992)$ methodology to test for the existence of longterm equilibrium relationships among the variables, looking for cointegration vectors.

Table 1 - Unit Root Tests

\begin{tabular}{|c|c|c|c|c|c|c|}
\hline \multicolumn{7}{|c|}{$\begin{array}{c}\text { Augmented Dickey-Fuller (ADF) } \\
\mathrm{H}_{\mathrm{O}}=\text { there is a unit root }\end{array}$} \\
\hline & $\begin{array}{l}\text { Statistic value of the } \\
\text { series in levels }\end{array}$ & $\begin{array}{l}\text { Rejection } \\
\text { up to } 95 \%\end{array}$ & $\mathrm{HO}$ & $\begin{array}{l}\text { Statistical value of the } \\
\text { series in first differences }\end{array}$ & $\begin{array}{l}\text { Rejection } \\
\text { up to } 95 \%\end{array}$ & $\mathrm{HO}$ \\
\hline LTour_Arg & $\begin{array}{l}0.076321 \\
\text { (no constant, } \\
13 \text { lags) }\end{array}$ & No & & $\begin{array}{l}-4.286 .977 \\
\text { (no constant, } \\
12 \text { lags) }\end{array}$ & Yes & \\
\hline LTour_USA & $\begin{array}{l}1.004 .104 \\
\text { (no constant, } \\
13 \text { lags) }\end{array}$ & No & & $\begin{array}{l}-3.858 .005 \\
\text { (no constant, } \\
12 \text { lags) }\end{array}$ & Yes & \\
\hline LIPI_Arg & $\begin{array}{l}1.100 .784 \\
\text { (no constant, } \\
13 \text { lags) }\end{array}$ & No & & $\begin{array}{l}-3.179 .880 \\
\text { (no constant, } \\
14 \text { lags) }\end{array}$ & Yes & \\
\hline LIPI_USA & $\begin{array}{l}0.481431 \\
\text { (no constant, } \\
7 \text { lags) }\end{array}$ & No & & $\begin{array}{l}-3.613 .775 \\
\text { (no constant, } \\
3 \text { lags) }\end{array}$ & Yes & \\
\hline LRER_Arg & $\begin{array}{l}-0.698396 \\
\text { (no constant, } \\
11 \text { lags) }\end{array}$ & No & & $\begin{array}{l}-6.130 .425 \\
\text { (no constant, } \\
10 \text { lags) }\end{array}$ & Yes & \\
\hline LRER_USA & $\begin{array}{l}0.030842 \\
\text { (no constant, } \\
7 \text { lags) }\end{array}$ & No & & $\begin{array}{l}-6.068 .407 \\
\text { (no constant, } \\
6 \text { lags) }\end{array}$ & Yes & \\
\hline LRER_Arg_Bra & $\begin{array}{l}-0.043243 \\
\text { (no constant, } \\
10 \text { lags) } \\
\text { (no constant, } \\
5 \text { lags) }\end{array}$ & No & & $\begin{array}{l}-6.614 .358 \\
\text { (no constant, } \\
4 \text { lags) } \\
\text { (no constant, } \\
12 \text { lags) }\end{array}$ & Yes & \\
\hline Lags are calcul & ed following Akaike crite & & & & & \\
\hline
\end{tabular}

\subsubsection{Johansen Cointegration Methodology}

Following Enders (1995), cointegration analysis is based on an autoregressive vector with VECM specification for an endogenous variable vector.

$$
\begin{aligned}
& \Delta X_{i t}=A_{1} \Delta X_{i t-1}+\cdots+A_{k} \Delta X_{i t-k+1}+\prod X_{i t-k}+\mu+\Gamma D_{t}+\xi_{t} \\
& \mathrm{t}=1, \ldots, \mathrm{T} \\
& \text { where } \xi_{-}(\mathrm{t}) \sim \mathrm{N}\left(0, \sigma^{\wedge} 2\right)
\end{aligned}
$$

$\mu$ is a vector of constants and Dt contains a set of dummy variables (seasonal and interventions). 
Information about long-term relationships is included in the $\Pi=\alpha \beta^{\prime}$ matrix, where $\beta$ is the coefficient's vector for the existing equilibrium relationships and $\alpha$ is the vector for short-term adjustment mechanism coefficients. The identification of the range of the matrix $\prod$ determines the total cointegration relationships existing among the variables.

Once having examined the long-term relationship, we proceed to the short-term analysis, which shows different adjustment mechanisms of the variables to the long-run equilibrium.

\section{MAIN RESULTS}

To test for the existence of cointegration between the variables we apply the Johansen test, analyzing the results from the Trace and the Eigenvalue of matrix $\Pi$ (Tables 2 and 3 ). The existence of a cointegrating vector was not rejected, and the signs of the variables were as expected. Moreover, we also perform exclusion tests for $\beta$ coefficients and weak exogeneity tests for $\alpha$ coefficients, and all were significant. Furthermore, residuals were well behaved (see the Appendix). Also, some dummy variables were added to correct some outliers and special events' effects over the different series.

Table 2 - Cointegration Test for Uruguayan Tourism from Argentina (Model 1)

\begin{tabular}{|c|c|c|c|c|c|}
\hline \multicolumn{6}{|c|}{ Unrestricted Cointegration Rank Test (Trace) } \\
\hline $\begin{array}{l}\text { Hypothesized } \\
\text { no. of } \mathrm{CE}(\mathrm{s})\end{array}$ & Eigenvalue & Trace statistic & 0.05 & Critical value & Prob.** \\
\hline None * & 0.211155 & 78.66564 & 47.85613 & & 0.0000 \\
\hline At most $1 *$ & 0.097137 & 30.75410 & 29.79707 & & 0.0387 \\
\hline At most 2 & 0.046183 & 10.11277 & 15.49471 & & 0.2722 \\
\hline At most 3 & 0.002776 & 0.561436 & 38.41466 & & 0.4537 \\
\hline \multicolumn{6}{|c|}{ Trace test indicates 1 cointegrating eqn(s) at the 0.05 level } \\
\hline \multicolumn{6}{|c|}{ Unrestricted Cointegration Rank Test (Maximum Eigenvalue) } \\
\hline $\begin{array}{l}\text { Hypothesized } \\
\text { no. of } C E(s)\end{array}$ & Eigenvalue & Trace statistic & 0.05 & Critical value & Prob. ** \\
\hline None * & 0.211155 & 47.91155 & 27.58434 & & 0.0000 \\
\hline At most 1 & 0.097137 & 20.64133 & 21.13162 & & 0.0584 \\
\hline At most 2 & 0.046183 & 9.551331 & 14.26460 & & 0.2431 \\
\hline At most 3 & 0.002776 & 0.561436 & 3.841466 & & 0.4537 \\
\hline \multicolumn{6}{|c|}{$\begin{array}{l}\text { Max-eigenvalue test specifies } 1 \text { cointegrating eqn(s) at the } 0.05 \text { level } \\
* \text { indicates rejection of the hypothesis at the } 0.05 \text { level }-* * \text { MacKinnon-Haug-Michelis (1999) p-values }\end{array}$} \\
\hline
\end{tabular}

For the Uruguayan model, we found two cointegration vectors with the trace test, but only one with Maximum Eigenvalue. So, we consider only one long-run cointegration vector between the variables, as the second one must be between some of the external variables, which in this case is not in our scope of study.

In this model, we also tested the possible inclusion of the RER between Argentina and Brazil, as Brazil is the most important alternative destination of Argentine tourists coming to Uruguay, but it did not prove significant in either the short or the long term. However, we decided to keep it in the model due to the improvements in behavior of residuals.

The long-run cointegration vector estimated for the Uruguayan model is:

$$
\text { LTour_Arg } g_{t}=2.987 \text { LIPI_Arg }{ }_{\mathrm{t}}+2.651 L R E R \_A r g_{\mathrm{t}}-14.0727
$$

Both coefficients were significantly different from zero, and the LIPI_Arg coefficient was nearly 3 , and as this variable is a proxy of (log of) Argentinian's income, its coefficient is a proxy of the income elasticity of tourism to Uruguay, and as a luxury expenditure, it was greater than 1 . The RER coefficient represents the relative prices elasticity of tourism, and the result was greater than 2.5 , showing that tourists react firmly to small 
changes in relative prices. Under each coefficient we have the t-value of the coefficient estimation, showing the significance of the estimation.

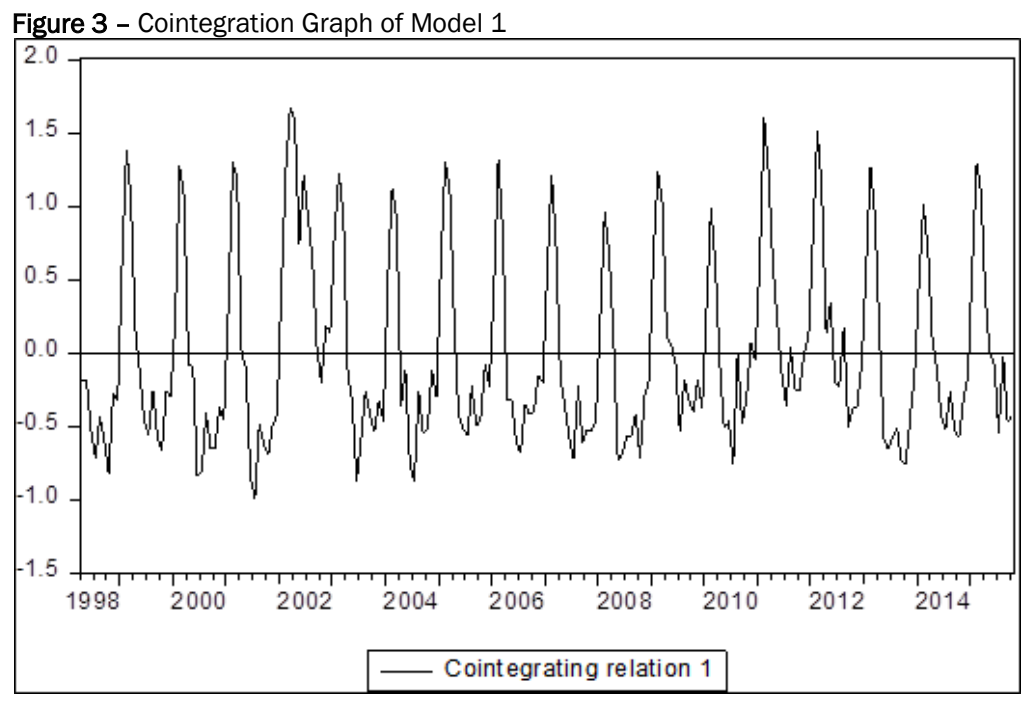

Source: Author's calculations

In Figure 3 we can see the cointegration graph of Model 1, where the great impact of seasonality in the relationship is evident. During the 2002 crisis the relationship was above the equilibrium, showing that despite the fall in economic activity in both countries (Argentina and Uruguay), and the sharp changes in relative prices, tourism did not suffer in the same way.

Table 3 - Cointegration Test for Mexican Tourism from USA (Model 2)

\begin{tabular}{|c|c|c|c|c|}
\hline \multicolumn{5}{|c|}{ Unrestricted Cointegration Rank Test (Trace) } \\
\hline $\begin{array}{l}\text { Hypothesized } \\
\text { no. of CE(s) }\end{array}$ & Eigenvalue & Trace statistic & $\begin{array}{l}0.05 \\
\text { critical value }\end{array}$ & Prob. ** \\
\hline None * & 0.167156 & 5.048 .001 & 2.979 .707 & 0.0001 \\
\hline At most 1 & 0.064341 & 1.353 .252 & 1.549 .471 & 0.0967 \\
\hline At most 2 & 0.000489 & 0.098767 & 3.841 .466 & 0.7533 \\
\hline \multicolumn{5}{|c|}{$\begin{array}{l}\text { Trace test indicates } 1 \text { cointegrating eqn(s) at the } 0.05 \text { level } \\
* \text { indicates rejection of the hypothesis at the } 0.05 \text { level }-* * \text { MacKinnon-Haug-Michelis (1999) p- } \\
\text { values }\end{array}$} \\
\hline \multicolumn{5}{|c|}{ Unrestricted Cointegration Rank Test (Maximum Eigenvalue) } \\
\hline $\begin{array}{l}\text { Hypothesized } \\
\text { no. of CE(s) }\end{array}$ & Eigenvalue & Trace statistic & $\begin{array}{l}0.05 \\
\text { critical value }\end{array}$ & Prob.** \\
\hline None * & 0.167156 & 3.694 .749 & 2.113 .162 & 0.0002 \\
\hline At most 1 & 0.064341 & 1.343 .376 & 1.426 .460 & 0.0673 \\
\hline At most 2 & 0.000489 & 0.098767 & 3.841 .466 & 0.7533 \\
\hline
\end{tabular}

Max-eigenvalue test specifies 1 cointegrating eqn(s) at the 0.05 level

*indicates rejection of the hypothesis at the 0.05 level - **MacKinnon-Haug-Michelis (1999) p-values

Source: Author's calculations

The long-run cointegration vector for Mexican model is:

$$
\begin{gathered}
\text { LTour_USA } \\
=2.336 \text { LIPI_USA }_{\mathrm{t}}+1.981 R E R \_U S A_{\mathrm{t}}-12.295 \\
(7.83562)
\end{gathered}
$$

In the Mexican model, the coefficients were smaller than for the Uruguayan model but significantly greater than 1, also confirming that tourism is a luxury good (or service) for US-origin tourists visiting Mexico. Nevertheless, the characteristics of American visitors' to Mexico, include components which are business or other 
reasons different from recreational travel. And this behavior can explain why the results for visitors to Mexico show smaller coefficients than those for visitors to Uruguay.

In Figure 4 we can see the cointegration graph of Model 2, where the great impact of seasonality in the relationship is also evident. During the 2008-2009 international crisis, the relationship was below the equilibrium, showing a big, but short, impact on Americans visiting Mexico. At the end of the period, the relationship is again below the equilibrium path.

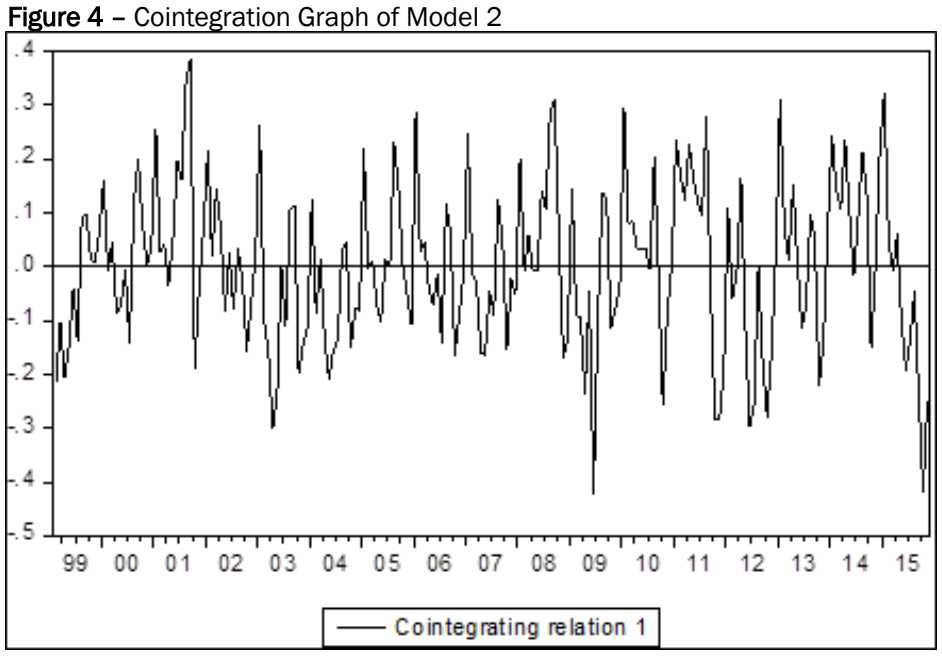

Source: Author's calculations

\subsection{Impulse response functions}

The impulse response functions help to understand the dynamic interactions that characterize the system estimated. They allow us to identify them using the model simulation. As all the variables in a VEC model are endogenous, we simulate a shock on some variables to see the impact on the variables that we are interested in seeing how they react. In this case, we simulate a shock on Argentina's income (LIPI_Arg) and on relative prices (LRER_Arg), to see the impact on Argentinian tourists visiting Uruguay (Figure 5). For the second model, we simulate a shock on US income (LIPI_USA) and on relative prices (LRER_USA), to see the impact on USA citizens' tourists visiting Mexico (Figure 6).

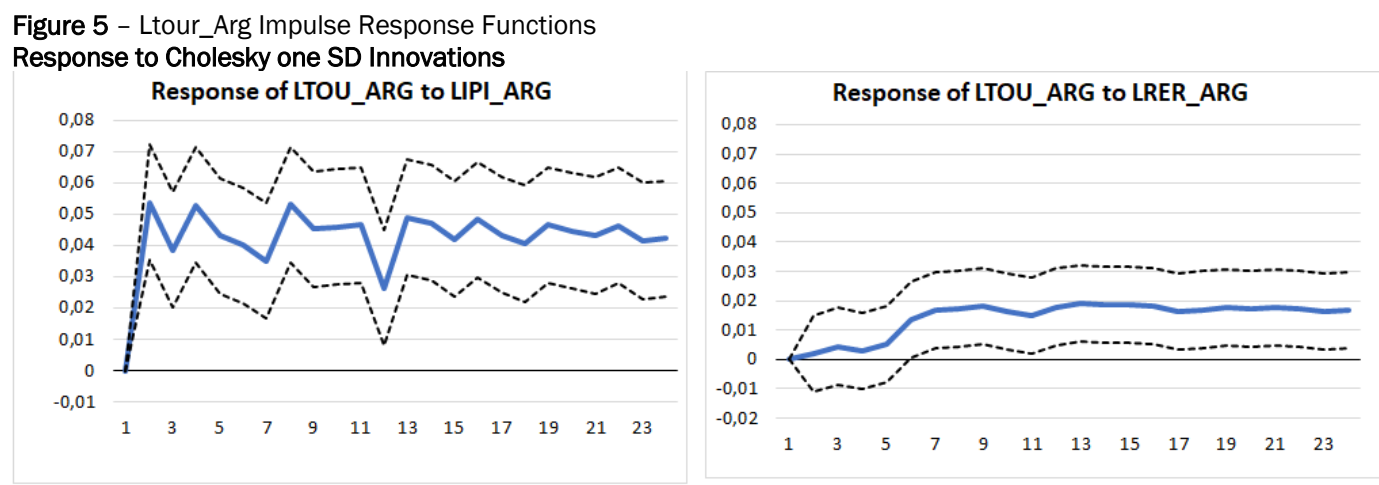

Source: Author's calculations. Confidence intervals built considering +-2 SD.

Figure 5 enables to observe the impulse response functions of a shock on Argentinians' income (LIPI_Arg) and on relative prices between Uruguay and Argentina (LRER_arg), on Argentinian tourists visiting Uruguay. Both have a positive and permanent impact, and both are significant. This result has a high relevance for policymakers, considering the importance of Argentinians' income situation when they decide how to spend their holidays due to the positive relative price shocks (measured as RER). After a shock equivalent to one standard deviation (S.D.) and approximately 8 months, there is an impact of $2 \%$ increase in the number of 
tourists. Additionally, an income shock might be expected to have an immediate effect: after two months the number of tourists would increase by nearly $5 \%$.

This result can also be a consequence of the special characteristic of Argentinian tourists: nearly $40 \%$ of Argentinian tourists use their own houses in Uruguay or visit some relatives (Brida, Monterubbianesi \& Serviansky, 2012), what is known as "captive tourism".

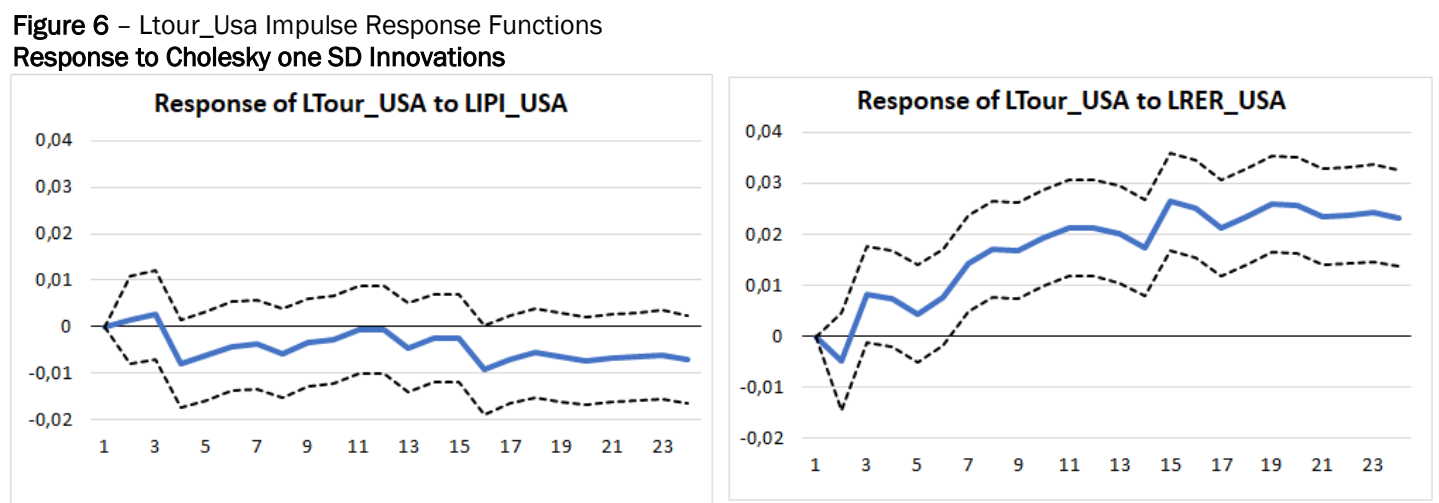

Source: Author's calculations. Confidence intervals built considering +-2 SD.

In the case of American tourists traveling to Mexico (Figure 6), the impulse response function shows a slightly negative but not significant impact of a shock on US income, but a positive and significant response of tourists to a shock on bilateral RER between the USA and Mexico. From these results, we can conclude that the Mexican demand from American tourists depends on the bilateral real exchange rate, and income changes have no impact in the considered period (January 1998 to December 2015).

\subsection{Forecasts}

As the data used in the models is only up to 2015, using the model obtained through the estimation we made a forecast for 2016 and 2017, and compared it to the actual data, to see the predictive power of the model, and look for misbehaviors in the data, compared with what was expected afterward.

In Figure 7 we have the actual data for Argentinian tourists visiting Uruguay up to July 2017 and the forecast from the model up to December 2017.

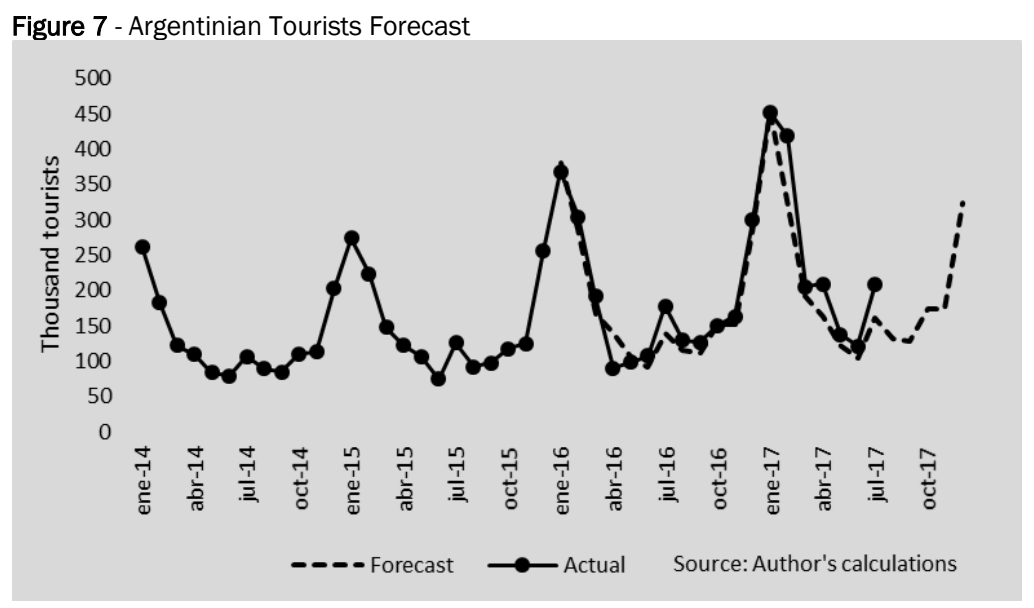

Source: Author's calculations

The forecast model for 2016 predicts a $20.4 \%$ increase whereas the real data shows a $25 \%$ increase. The difference is due to some institutional changes in Argentina in 2016 as a consequence of a new president in power, that changed the accessibility of buying foreign currency to travel. 
In Figure 8 we have the actual data for American tourists visiting Mexico up to December 2016 and the forecast from the model up to December 2017.

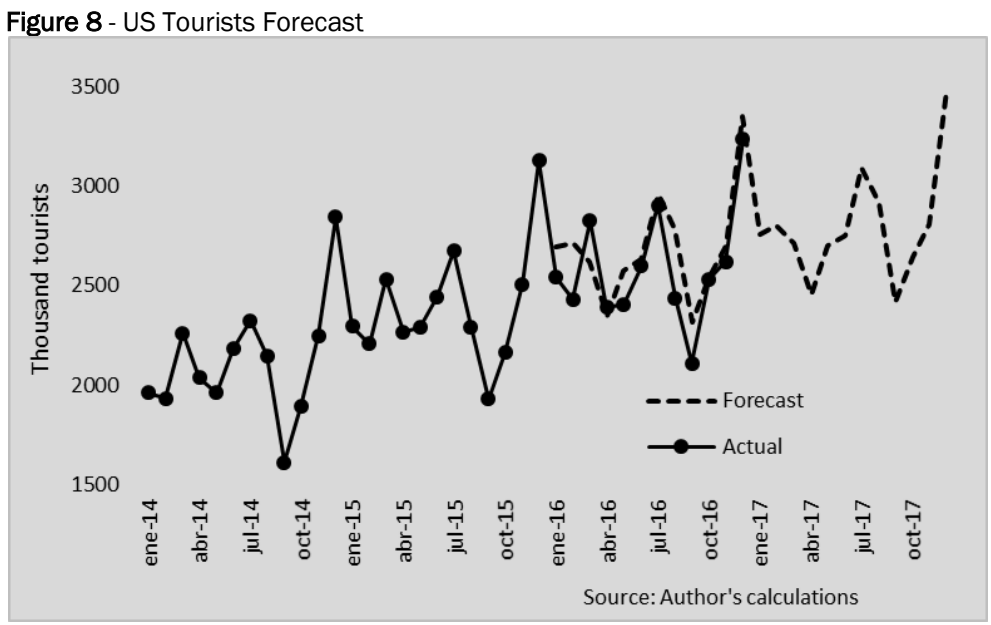

Source: Author's calculations

The forecast model for 2016 predicted $12.2 \%$ increase whereas the real data shows an $8 \%$ increase. The difference must be related to the president in the USA in 2017, Donald Trump and politics against Mexico. Nevertheless, according to Mexican authorities, the tourism sector in 2016 achieved a record, highlighting the increase in US tourists.

\section{FINAL REMARKS}

The main objective of this research was to estimate and compare the tourism demand for Uruguay and Mexico from the main outbound tourism countries: Argentina for Uruguay and the USA for Mexico. Tourism is frequently viewed as an important engine for the economic growth and development of countries. In Mexico, domestic trips have become a notable feature but the main tourism exports are from international travelers for whom Mexico was the 9th most attractive country in 2015 and 58.3\% of total tourists came from the USA. For Uruguay, total yearly tourists is equivalent to about $90 \%$ of its population, Argentinian tourists being nearly $60 \%$ of this total and historically the main visitors.

This objective was instrumented through the estimation of two models, one for each country, through the Johansen methodology. We found one long-term relationship for each country's tourist demand, both including IPI as a monthly proxy for the income of the origin tourism country and the bilateral real exchange rate as a proxy for relative prices between Mexico and the USA on the one hand, and Uruguay and Argentina on the other.

We found one cointegration relationship for each country, through VECM. Contrary to what was found in Álvarez-Díaz et al. (2015), where income-elasticities were lower than unity, the coefficients of the equation imply income-elasticity of greater than 2 for American tourists in Mexico, and nearly 3 for Argentinian tourists in Uruguay. The two models show income-elasticities greater than 1, showing that the characteristic of "luxury" good can be applied to tourism for these two cases. Bilateral RERs were also significant in both models. Therefore, income and prices matter for tourists' traveling decisions. For six different world regions, Gunter and Smeral (2016) found a decline in tourism income elasticities, using panel data analysis, and for the last decade, the values of the income elasticities were below 1. But other works such as Botzoris et al. (2014) or Dritsakis (2004) found income elasticities greater than 1.

These results have important consequences for tourists' decisions, so policymakers from the public sector and private sector decision-makers must take them into consideration when formulating policies or planning future actions. First, they must take into account the economic situation of the visiting economy, mainly GDP growth. Then, they must look at the evolution of relative prices through real exchange rates, which reveals the purchasing power of tourists in the country they visit, and in case this relation is in comparison with the country issuing tourism, so it would be positive to take some measures related to prices. 
Through the impulse response functions, we can appreciate the difference between both country's tourism demands. In the case of Uruguay, shocks on both variables (income and relative prices) produce an impact on the number of Argentinian tourists visiting Uruguay, but the income's impact (here estimated through the monthly IPI) resulted in more than double than impact of prices (estimated through bilateral RER). The impact of an income shock has an immediate effect on the Argentinian tourists visiting Uruguay, almost $5 \%$ by the second month after the shock. In the case of the RER, the impact reaches $2 \%$ within 8 months. This result can also be a consequence of the special characteristic of Argentinian tourists: nearly $40 \%$ of Argentinian tourists use their own houses in Uruguay or visit some relatives (Brida et al., 2012), what is known as "captive tourism".

A shock on the US income simulated by the impulse response functions shows no significant impact on the number of USA tourists visiting Mexico. But there is a significant impact of an RER shock, that reaches $2.5 \%$ within 14 months. This result must be indicating that American visitors take into account prices between possible destinations when deciding whether to travel to Mexico or not, and that there is no "captive tourism" in this case.

Finally, we made forecasts for 2016 and 2017 using the estimated model and compared them to the actual data. In both countries, there have been institutional changes related to the presidential elections in 2015 and 2016, that the model did not have in its information. In the case of Uruguay, the change in Argentina was favorable for tourism, and real data was greater than that predicted by the model. On the other hand, the new USA president negatively affected US tourism to Mexico, so predictions were higher than the actual data.

These results are crucial when studying the behavior of tourism stakeholders. The private and public sectors must consider them as an additional instrument for planning, elaborating, and implementing future strategies or policies for this particular sector.

\section{REFERENCES}

Adnan Hye, Q. M. \& Ali Khan, R. E. (2013). Tourism-led growth hypothesis: A case study of Pakistan. Asia Pacific Journal of Tourism Research, 18(4), 303-313. https://doi.org/10.1080/10941665.2012.658412

Altmark, S.; Mordecki, G.; Risso, W.A., \& Santiñaque, F. (2013). Argentinian and Brazilian demands for tourism in Uruguay. Tourism Analysis, $173-182$. https://doi.org/10.3727/108354213X13645733247738

Álvarez-Díaz, M.; Otero-Giráldez, M. S. \& González-Gómez, M. (2015). La modelización de la demanda de turismo de economías emergentes: El caso de la Llegada de Turistas Rusos a España. Working Paper: 15/03. June 2015, Universidad de Vigo. https://doi.org/10.1016/i.cesjef.2015.10.001

Álvarez-Díaz, M.; Otero-Giráldez, M. S. \& González-Gómez, M. (2012). Estimating international tourism demand to Spain separately by the major source markets. Working Paper: 12/04, Universidad de Vigo.

Botzoris, G.; Varagoulia, E.; Profillidisa, V.; Papadopoulosa B. \& Lathirasb P. (2014). Forecast of tourism demand with the use of fuzzy and cointegration econometric techniques. Journal of Computational Methods in Sciences and Engineering, 14(5), 245-257. http://dx.doi.org/10.3233/JCM-140501

Brida, J.; Lanzilotta, B. \& Risso, W. (2010). The tourism-led growth hypothesis for Uruguay, Tourism Economics, 16(3),765-771. https://doi.org/10.5367/000000010792278356

Brida, G.; Monterubbianesi, P.D. \& Serviansky, M. (2012). El impacto del costo de transporte en la demanda de turismo receptivo argentino en Uruguay. Un análisis desagregado de cointegración y causalidad. TURyDES 5(12), 1-28.

Cao, Z.; Li, G. \& Song, H. (2017). Modelling the interdependence of tourism demand: The global vector autoregressive approach. Annals of Tourism Research, 67, 1-13. https://doi.org/10.1016/j.annals.2017.07.019

Chon, K. S.; Pine, R. J.; Lam, T. \& Zhang, H. Q. (2013). Tourism and hotel development in China: From political to economic success. Routledge. https://doi.org/10.4324/9780203048320

Chou, M. C. (2013). Does tourism development promote economic growth in transition countries? A panel data analysis. Economic Modelling, 33, 226-232. http://dx.doi.org/10.1016/j.econmod.2013.04.024 
Consejo Nacional Empresarial Turístico - CNET (2017). Panorama de la actividad turística en México. CNET: Cidade do México. Disponível em: https://www.cnet.org.mx/panorama/no-20

Costa, C.; Panyik, E. \& Buhalis, D. (2014). A comparative approach to European tourism planning and organisation systems: An introduction. In: Costa, C; Panyik, E.; Buhalis, D. (ed.) European Tourism Planning and Organisation Systems: The EU Member States, Bristol: Channel View Publication. https://doi.org/10.13140/2.1.3978.0163

Crouch, G. I. (1995). A meta-analysis of tourism demand. Annals of Tourism Research, 22(1), 103-118. https://doi.org/10.1016/0160-7383(94)00054-V

Desplas, N. (2010). La oferta turística de la sierra tarahumara: su caracterización y sus potencialidades para el turista europeo. Talleres gráficos del Estado de Chihuahua. México: Secretaría de Desarrollo Comercial yTurístico, 1-71.

Dritsakis, N. (2004). Cointegration analysis of German and British tourism demand for Greece. Tourism Management, 25(1), 111-119. http://dx.doi.org/10.1016/S0261-5177(03)00061-X

Enders, W. (1995). Applied econometric time series. John Wiley and Sons, Inc. Editors.

Ghimire, K. B. (ed.) (2013). The native tourist: Mass tourism within developing countries. Routledge. https://doi.org/10.1002/jid.894

González, P. \& Moral, P. (1995). An analysis of the international tourism demand in Spain. International Journal of Forecasting, 11(2), 233-251. https://doi.org/10.1016/0169-2070(94)00570-3

Gunter, U. \& Smeral, E. (2016). The decline of tourism income elasticities in a global context. Tourism Economics. 22(3), 466-483. https://doi.org/10.5367/te.2014.0431

Han, Z.; Durbarry, R. \& Sinclair, M. T. (2006). Modeling US tourism demand for European destinations. Tourism Management, 27(1), 1-10. https://doi.org/10.1016/j.tourman.2004.06.015

Hong Kong Tourism Board (2014). Hong Kong, the facts. Honh Kong Government. December 2014 in the link: http://www.gov.hk/en/about/abouthk/factsheets/docs/tourism.pdf

Johansen, S. (1988). Statistical analysis of cointegration vectors. Journal of Economic Dynamics and Control, 12(2-3), 231-254. https://doi.org/10.1016/0165-1889(88)90041-3

Johansen, S. (1992). Cointegration in partial systems and the efficiency of single-equation analysis. Journal of Econometrics, 52(3), 389-402. https://doi.org/10.1016/0304-4076(92)90019-N

Karimi, A.; Faroughi, P. \& Rahim, K. A. (2015). Modeling and forecasting of international tourism demand in ASEAN Countries. American Journal of Applied Sciences, 12(7), 479.486. http://dx.doi.org/10.3844/ajassp.2015.479.486

Krugman, P. \& Obstfeld, M. (2008). International economics: Theory and policy, International Edition, 8th ed. Pearson, Addison Wesley.

Lim, C. (1997). Review of international tourism demand models, Annals of Tourism Research, 24(4), 835849. https://doi.org/10.1016/S0160-7383(97)00049-2

Lim, C. \& McAleer, M. (2001). Modelling the determinants of international tourism demand to Australia. The Institute of Social and Economic Research, Osaka University.

Martins, L.F.; Gan, Y. \& Ferreira-Lopes, A. (2017). An empirical analysis of the influence of macroeconomic determinants on World tourism demand. Tourism Management, 61, 248-260.

Meré, D. (2016). Recibe México turistas de EU como nunca. Periódico Reforma. Mexico. March, 2016

Mudambi, R. \& Baum, T. (1997). Strategic segmentation: an empirical analysis of tourist expenditure in Turkey. Journal of Travel Research, 36(1), 29-34. https://doi.org/10.1177\%2F004728759703600105

Nurbaizura, B. \& Zainudin, A. (2015). Estimating international tourism demand for Malaysia. Proceedings of the International Conference on Natural Resources, Tourism and Services Management. Sabah, Malaysia,

OPP (2009). Estrategia Uruguay III siglo. Aspectos productivos. Working paper, Oficina de Planeamiento y Presupuesto, Uruguay.

Pablo-Romero, M. D. P. and Molina, J. A. (2013). Tourism and economic growth: A review of empirical literature. Tourism Management Perspectives, 8, 28-41. http://dx.doi.org/10.5772/62276 
Pham, T. D.; Nghiem, S. \& Dwyer, L. (2017). The determinants of Chinese visitors to Australia: A dynamic demand analysis. Tourism Management, 63, 268-276. http://dx.doi.org/10.1016/j.tourman.2017.06.015

Paraskevopolous, G. (1977). An econometric analysis of international tourism, Lecture Series No. 31, Centre of Planning and Economic Research, Athens, Greece.

Peterson, R. R.; Cardenas, D. \& Harrill, R. (2014). Tourism as a catalyst for economic development in Latin America: Setting an agenda for policy and research. Tourism Analysis, 19(1), 117-122. http://dx.doi.org/10.3727/108354214X13927625340433

Ribeiro, M. A.; Oom do Valle, P. \& Silva, J. A. (2013). Residents' attitudes towards tourism development in Cape Verde islands. Tourism Geographies, 15(4), 654-679. http://dx.doi.org/10.1080/14616688.2013.769022

Ridderstaat J.; Croes R. \& Nijkamp P. (2014), Tourism and long-run economic growth in Aruba. International Journal of Tourism Research, 16(5), 472-487. http://dx.doi.org/10.1002/jtr.1941

Robano, V. (2000). Determinantes del turismo receptivo en Uruguay, Proceedings of the XV Jornadas de Economía del Banco Central del Uruguay, Montevideo.

Sánchez, M., Pulido, J. I. \& Cárdenas, P. J. (2013). Tourism growth versus economic development: An analysis by multivariate techniques. In: Matias, A.; Nijkamp, P. \& Sarmento, M. Quantitative Methods in Tourism Economics. Physica-Verlag HD. https://doi.org/10.1007/978-3-7908-2879-5_13

Schubert, S. F.; Brida, J. G. \& Risso, W. A. (2011). The impacts of international tourism demand on economic growth of small economies dependent on tourism. Tourism Management, 32(2), 377-385. https://doi.org/10.1016/j.tourman.2010.03.007

Secretaría de Turismo de México (2016), México primer lugar del “TOP 10" de sitios para turismo de lujo, Mexico, Gobierno de Mexico. February 2016: http://www.gob.mx/sectur/prensa/mexico-primer-lugar-deltop-10-de-sitios-para-turismo-de-lujo

Serviansky, M. (2011). El impacto del costo del transporte en la demanda de turismo receptivo argentino en Uruguay. Un análisis desagregado de cointegración y causalidade. Thesis (Master degree in Economics), Universidad de la República de Uruguay, Montevideo, Uruguay.

Song, H. \& Li, G. (2008). Tourism demand modelling and forecasting - A review of recent research. Tourism Management, 29(2), 203-220. https://doi.org/10.1016/j.tourman.2007.07.016

Song, H.; Li, G.; Witt, S.F. \& Fei, B. (2010). Tourism demand modelling and forecasting: how should demand be measured? Tourism Economics, 16(1), 63-81. https://doi.org/10.5367/000000010790872213

Stronge, W. \& Redman, M., (1982). USA tourism in Mexico: An empirical analysis. Annals of Tourism Research, 9(1), 21-35. https://doi.org/10.1016/0160-7383(82)90032-9

Tang, C. F. \& Tan, E. C. (2013). How stable is the tourism-led growth hypothesis in Malaysia? Evidence from disaggregated tourism markets. Tourism Management, 37, 52-57. https://doi.org/10.1016/j.tourman.2012.12.014

Timothy, D. J. (2014). Trends in Tourism, Shopping, and Retailing. In: Lew, A. A.; Hall, C. M. \& Williams, A. M. The Wiley Blackwell Companion to Tourism, John Wiley \& Sons Ltd. https://doi.org/10.1002/9781118474648.ch30

Truett, D. \& Truett, L. (1987). The response of tourism to international economic conditions: Greece, Mexico, and Spain. The Journal of Developing Areas, 21(2), 177-90.

Tugcu, C. T. (2014). Tourism and economic growth nexus revisited: A panel causality analysis for the case of the Mediterranean Region. Tourism Management, 42, 207-212. https://doi.org/10.1016/j.tourman.2013.12.007

Uruguayan Ministry of Tourism, Uruguay. In: http://mintur.gub.uy/index.php/estadisticas/turismo-receptivo

Witt, S.F. and Witt, C. A. (1995). Forecasting tourism demand: A review of empirical research. International Journal of Forecasting Volume 11, Issue 3, Pages 447-475. https://doi.org/10.1016/01692070(95)00591-7

World Tourism Organization (UNWTO, 2011). Tourism Towards 2030 / Global Overview - Advance edition presented at UNWTO 19th General Assembly - 10 October 2011

World Tourism Organization - UNWTO (2014). UNWTO World Tourism Barometer. Retrieved December 10, 2015, from http://mkt.unwto.org/barometer 
White House (2014). Fact sheet: and report: President Obama Visits Cooperstown to Highlight Travel and Tourism that is Growing our Economy and Creating Jobs. Retrieved December 11, 2014, from http://www.whitehouse.gov/the-press-office/2014/05/22/fact-sheet-report-president-obama-visits-cooperstown-highlight-travel-an

World Travel and Tourism Council - WTTC (2011). WTTC annual reports, progress and priorities 2011/11. The World Travel and Tourism Council.

\section{Information about the authors}

\section{Gabriela Mordecki}

Associated Professor, Full time, Director, Instituto de Economia (IECON), FCEA, UDELAR, Uruguay. Master's level diploma in "Trade modelling and Policy: Regional Economic Integration" Antwerp University (UFSIA), Belgium, October 2000. Specialization in Industrial Economy, Blumenau Regional University (FURB), Brazil, March 1992. Economist, July 1986, UDELAR, Uruguay.

Contribution: research design, literature review, data analysis, discussion of results. Final writing of the document. of authors (April 2019).

E-mail: gabriela@iecon.ccee.edu.uy

ORCID: https://orcid.org/0000-0002-1097-3514

\section{Ana Cecilia Leiva}

Master Student, University of Oslo, Finland. Economist, December 2016, UDELAR, Uruguay.

Contribution: literature review, data analysis, discussion of results. Part of the drafting process.

E-mail: aleivavernengo@gmail.com

ORCID: https://orcid.org/0000-0002-1123-9354

\section{Nathalie Desplas Puel}

Tenure Professor and Director of the Tourism Research Center at Tecnológico de Monterrey, Chihuahua, Mexico. Visiting professor in Hungary and USA. Economics Sciences PhD, University of La Havana, Cuba. Economic Sciences Master's Degree, La Sorbonne University, Paris, France.

Contribution: research design, discussion of results. Part of the drafting process.

E-mail: nathalie.desplas@itesm.mx

ORCID: https://orcid.org/0000-0001-7795-4038 


\section{APPENDIX}

Model 1 - Uruguayan tourism demand from Argentina

Normality residual tests

VEC Residual Normality Tests

Orthogonalization: Cholesky (Lutkepohl)

Null Hypothesis: residuals are multivariate normal

Date: 08/31/16 Time: 14:11

Sample: 1998M01 2015M12

Included observations: 202

Skewness

Chi-sq

df

Prob.

\begin{tabular}{|c|c|c|c|c|}
\hline 1 & -0.168940 & 0.960868 & 1 & 0.3270 \\
\hline 2 & 0.035830 & 0.043220 & 1 & 0.8353 \\
\hline 3 & 0.153168 & 0.789834 & 1 & 0.3742 \\
\hline 4 & 0.230985 & 1.796249 & 1 & 0.1802 \\
\hline Joint & & 3.590171 & 4 & 0.4643 \\
\hline Component & Kurtosis & Chi-sq & df & Prob. \\
\hline 1 & 2.991325 & 0.000633 & 1 & 0.9799 \\
\hline 2 & 3.661738 & 3.685636 & 1 & 0.0549 \\
\hline 3 & 3.572679 & 2.760342 & 1 & 0.0966 \\
\hline 4 & 3.327121 & 0.900652 & 1 & 0.3426 \\
\hline Joint & & 7.347263 & 4 & 0.1186 \\
\hline Component & Jarque-Bera & df & Prob. & \\
\hline 1 & 0.961501 & 2 & 0.6183 & \\
\hline 2 & 3.728856 & 2 & 0.1550 & \\
\hline 3 & 3.550176 & 2 & 0.1695 & \\
\hline 4 & 2.696900 & 2 & 0.2596 & \\
\hline Joint & 10.93743 & 8 & 0.2053 & \\
\hline
\end{tabular}

Autocorrelation residual tests

VEC Residual Serial Correlation LM Tests

Null Hypothesis: no serial correlation at lag or-

der $\mathrm{h}$

Date: 08/31/16 Time: 15:25

Sample: 1998M01 2015M12

Included observations: 202

$\begin{array}{lll}\text { Lags } & \text { LM-Stat } & \text { Prob } \\ 1 & 15.69975 & 0.4741 \\ 2 & 13.99723 & 0.5989 \\ 3 & 25.00851 & 0.0697 \\ 4 & 20.55264 & 0.1964 \\ 5 & 22.50152 & 0.1277 \\ 6 & 17.28593 & 0.3673\end{array}$




\begin{tabular}{lll}
7 & 20.88412 & 0.1830 \\
8 & 25.01981 & 0.0695 \\
9 & 28.67583 & 0.0262 \\
10 & 16.70165 & 0.4052 \\
11 & 16.98878 & 0.3863 \\
12 & 27.96959 & 0.0319 \\
\hline
\end{tabular}

Probs from chi-square with $16 \mathrm{df}$.

\begin{tabular}{|c|c|c|c|c|}
\hline \multicolumn{5}{|c|}{ Vector Error Correction Estimates } \\
\hline \multicolumn{5}{|c|}{ Date: 08/31/16 Time: 15:26 } \\
\hline \multicolumn{5}{|c|}{ Sample (adjusted): 1999M01 2015M10 } \\
\hline \multicolumn{5}{|c|}{ Included observations: 202 after adjustments } \\
\hline \multicolumn{5}{|c|}{ Standard errors in ( ) and t-statistics in [ ] } \\
\hline \multicolumn{5}{|c|}{ Cointegration Restrictions: } \\
\hline \multicolumn{5}{|c|}{$B(1,1)=1, B(1,4)=0, A(4,1)=0$} \\
\hline \multicolumn{5}{|c|}{ Convergence achieved after 9 iterations. } \\
\hline \multicolumn{5}{|c|}{ Restrictions identify all cointegrating vectors } \\
\hline \multicolumn{5}{|c|}{ LR test for binding restrictions ( $r a n k=1)$ : } \\
\hline Chi-square(2) & 0.289454 & & & \\
\hline Probability & 0.865258 & & & \\
\hline Cointegrating Eq: & CointEq1 & & & \\
\hline LTOUR_ARG(-1) & 1.000000 & & & \\
\hline \multirow[t]{3}{*}{ LIPI_ARG(-1) } & -2.986666 & & & \\
\hline & $(0.30735)$ & & & \\
\hline & {$[-9.71742]$} & & & \\
\hline \multirow[t]{3}{*}{ LRER_ARG(-1) } & -2.651338 & & & \\
\hline & $(0.31737)$ & & & \\
\hline & {$[-8.35403]$} & & & \\
\hline LRER_ARG_BRA(-1) & 0.000000 & & & \\
\hline $\mathrm{C}$ & 14.72698 & & & \\
\hline Error Correction: & D(LTOUR_ARG) & D(LIPI_ARG) & D(LRER_ARG) & D(LRER_ARG_BRA) \\
\hline \multirow[t]{3}{*}{ CointEq1 } & -0.095385 & 0.019990 & 0.031544 & 0.000000 \\
\hline & $(0.03828)$ & $(0.01126)$ & $(0.00684)$ & $(0.00000)$ \\
\hline & [-2.49162] & [ 1.77535] & [ 4.61120] & {$[N A]$} \\
\hline
\end{tabular}

Model 2. Mexican tourism demand from USA

Normality residual tests

VEC Residual Normality Tests

Orthogonalization: Cholesky (Lutkepohl)

Null Hypothesis: residuals are multivariate normal

Date: 08/31/16 Time: 15:29

Sample: 1998M01 2015M12

Included observations: 202

Component Skewness Chi-sq df Prob.

$\begin{array}{lllll}2 & -0.075736 & 0.193108 & 1 & 0.6603\end{array}$

$\begin{array}{lllll}3 & 0.142713 & 0.685691 & 1 & 0.4076\end{array}$

$\begin{array}{llll}\text { Joint } & 1.115325 & 3 & 0.7734\end{array}$

Component Kurtosis Chi-sq df

1

$3.097711 \quad 0.080357 \quad 1$

0.7768 


\begin{tabular}{lclll}
2 & 2.882523 & 0.116158 & 1 & 0.7332 \\
3 & 3.320789 & 0.866123 & 1 & 0.3520 \\
Joint & & & & \\
& & 1.062638 & 3 & 0.7861 \\
Component & Jarque-Bera & df & Prob. & \\
1 & 0.316883 & 2 & 0.8535 & \\
2 & 0.309266 & 2 & 0.8567 & \\
3 & 1.551813 & 2 & 0.4603 & \\
Joint & 2.177962 & 6 & 0.9026 & \\
\hline
\end{tabular}

\begin{tabular}{|c|c|c|}
\hline \multicolumn{3}{|c|}{ Autocorrelation residual tests } \\
\hline \multirow{2}{*}{\multicolumn{3}{|c|}{$\begin{array}{l}\text { VEC Residual Serial Correlation LM Tests } \\
\text { Null Hypothesis: no serial correlation at lag or- } \\
\text { der h }\end{array}$}} \\
\hline & & \\
\hline \multicolumn{3}{|c|}{ Date: 08/31/16 Time: 15:29 } \\
\hline \multicolumn{3}{|c|}{ Sample: 1998M01 2015M12 } \\
\hline \multicolumn{3}{|c|}{ Included observations: 202} \\
\hline Lags & LM-Stat & Prob \\
\hline 1 & 8.499261 & 0.4847 \\
\hline 2 & 8.159813 & 0.5181 \\
\hline 3 & 10.47951 & 0.3131 \\
\hline 4 & 12.14074 & 0.2055 \\
\hline 5 & 15.26063 & 0.0840 \\
\hline 6 & 13.33584 & 0.1480 \\
\hline 7 & 6.503753 & 0.6886 \\
\hline 8 & 9.976442 & 0.3524 \\
\hline 9 & 19.39269 & 0.0221 \\
\hline 10 & 9.356655 & 0.4050 \\
\hline 11 & 11.28376 & 0.2568 \\
\hline 12 & 13.48303 & 0.1419 \\
\hline
\end{tabular}

Probs from chi-square with $9 \mathrm{df}$.

\begin{tabular}{|c|c|}
\hline $\begin{array}{l}\text { Estimated model } \\
\text { Vector Error Corre }\end{array}$ & timates \\
\hline Date: 08/31/16 & $5: 30$ \\
\hline Sample (adjusted & 102 2015M11 \\
\hline Included observat & 2 after adjustments \\
\hline Standard errors ir & t-statistics in [ ] \\
\hline Cointegration Res & \\
\hline $\mathrm{B}(1,1)=1, \mathrm{~A}(2$ & \\
\hline Convergence achi & er 10 iterations. \\
\hline Restrictions identi & ntegrating vectors \\
\hline LR test for binding & ons (rank = 1): \\
\hline Chi-square(1) & 0.954595 \\
\hline Probability & 0.328552 \\
\hline Cointegrating Eq: & CointEq1 \\
\hline LTOUR_USA(-1) & 1.000000 \\
\hline LIPI_USA(-1) & -2.335944 \\
\hline & $(0.29812)$ \\
\hline & {$[-7.83562]$} \\
\hline LRER_USA(-1) & -1.980517 \\
\hline & $(0.26982)$ \\
\hline & {$[-7.34006]$} \\
\hline 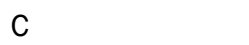 & 12.29525 \\
\hline
\end{tabular}




\begin{tabular}{llll} 
Error Correction: & D(LTOUR_USA $)$ & D(LIPI_USA) & D(LRER_USA) \\
CointEq1 & -0.149976 & 0.000000 & 0.073583 \\
& $(0.04857)$ & $(0.00000)$ & $(0.01817)$ \\
& {$[-3.08799]$} & {$[N A]$} & {$[4.04886]$} \\
\hline
\end{tabular}

Outliers and Dummy Variables Mexico - USA Model

\begin{tabular}{|c|c|c|c|c|c|}
\hline \multirow{2}{*}{ Period } & \multirow{2}{*}{ Type } & \multicolumn{3}{|l|}{ Influence } & \multirow[t]{2}{*}{ Observations } \\
\hline & & LTOUR_USA & LIPI_USA & LRER_USA & \\
\hline 2002.09 & $\mathrm{AO}$ & + & & & $\begin{array}{l}\text { Recovery nearly a year after } \\
2001.09\end{array}$ \\
\hline 2003.03 & $\mathrm{AO}$ & - & & & \\
\hline 2005.09 & $\mathrm{AO}$ & - & & & \\
\hline 2005.10 & $\mathrm{AO}$ & & + & & \\
\hline 2005.11 & $\mathrm{AO}$ & - & & & \\
\hline 2008.08 & $\mathrm{AO}$ & - & & & $\begin{array}{l}\text { Negative impact of interna- } \\
\text { tional crisis }\end{array}$ \\
\hline 2008.09 & $\mathrm{AO}$ & - & & & $\begin{array}{l}\text { Negative impact of interna- } \\
\text { tional crisis }\end{array}$ \\
\hline 2008.10 & $\mathrm{AO}$ & & + & + & \\
\hline 2008.12 & $\mathrm{AO}$ & - & - & & $\begin{array}{l}\text { Negative impact of interna- } \\
\text { tional crisis }\end{array}$ \\
\hline 2009.01 & $\mathrm{AO}$ & & - & & $\begin{array}{l}\text { Negative impact of interna- } \\
\text { tional crisis }\end{array}$ \\
\hline 2009.03 & $\mathrm{AO}$ & - & & & $\begin{array}{l}\text { Negative impact of interna- } \\
\text { tional crisis }\end{array}$ \\
\hline 2009.04 & $\mathrm{AO}$ & & & - & $\begin{array}{l}\text { Negative impact of interna- } \\
\text { tional crisis }\end{array}$ \\
\hline 2009.05 & $\mathrm{AO}$ & - & & & $\begin{array}{l}\text { Negative impact of interna- } \\
\text { tional crisis }\end{array}$ \\
\hline 2009.06 & $\mathrm{AO}$ & + & & & Recovery from crisis \\
\hline 2010.05 & $\mathrm{AO}$ & + & + & & Recovery from crisis \\
\hline 2010.06 & $\mathrm{AO}$ & - & & & \\
\hline 2011.03 & $\mathrm{AO}$ & + & & & Recovery from crisis \\
\hline 2014.01 & $\mathrm{AO}$ & + & & & USA economy growth \\
\hline
\end{tabular}

Uruguay - Argentina Model

\begin{tabular}{|c|c|c|c|c|c|c|}
\hline \multirow{2}{*}{ Period } & \multirow{2}{*}{ Type } & \multicolumn{4}{|l|}{ Influence } & \multirow[t]{2}{*}{ Observations } \\
\hline & & LTOUR_ARG & LIPI_ARG & LRER_ARG & LRER_ARG_BRA & \\
\hline 1999.01 & $\mathrm{AO}$ & + & & & & $\begin{array}{ll}1998 & \text { Argentina's } \\
\text { growth } & \end{array}$ \\
\hline 1999.02 & $\mathrm{AO}$ & & & & + & Brazilian devaluation \\
\hline 2000.05 & $\mathrm{AO}$ & - & & & + & $\begin{array}{l}\text { Argentina's GDP falling } \\
+ \text { Brazilian devaluation }\end{array}$ \\
\hline 2001.05 & $\mathrm{AO}$ & - & & & & Argentina's GDP falling \\
\hline 2001.09 & AO & & - & & & Argentina's GDP falling \\
\hline 2002.01 & $\mathrm{AO}$ & & & - & - & $\begin{array}{l}\text { Argentina's devalua- } \\
\text { tion }\end{array}$ \\
\hline 2002.02 & $\mathrm{AO}$ & & & - & - & $\begin{array}{l}\text { Argentina's devalua- } \\
\text { tion }\end{array}$ \\
\hline 2002.03 & $\mathrm{AO}$ & & - & - & - & $\begin{array}{l}\text { Argentina's crisis +Ar- } \\
\text { gentina's devaluation }\end{array}$ \\
\hline 2002.05 & $\mathrm{AO}$ & & & - & - & $\begin{array}{l}\text { Argentina's devalua- } \\
\text { tion }\end{array}$ \\
\hline 2002.07 & $\mathrm{AO}$ & & & & + & \\
\hline 2002.10 & AO & & & & - & $\begin{array}{l}\text { Argentina's devalua- } \\
\text { tion }\end{array}$ \\
\hline 2003.01 & AO & & & & + & \\
\hline
\end{tabular}


2003.06

$2004.03 \quad A O$

$2005.04 \quad A O$

$2006.03 \quad A O$

$2008.03 \quad A O$

$2011.03 \quad A O$

$2013.04 \quad A O$

2014.11 AO

$2015.02 \quad A O$

$\mathrm{AO}=$ Additive Outliers

Source: Author's calculations
Argentina's devaluation

Argentina's bad employment situation Argentina's bad employment situation Argentina's bad employment situation International crisis Argentina's growth Argentina's deterioration

Brazilian real's depreciation

Brazilian real's depreciation 